\title{
THE GENUS MIMOSA WITH SPECIAL REFERENCE TOM. QUADRIVALVIS L. VAR. LEPTOCARPA (D.C.) EARNEDY, A NEW SPECIES RECORD FOR THE WEED FLORA INMALAYSIA ${ }^{*}$
}

\author{
BAKI, B. BAKAR, H. NOORMA WATI and M.A. HAJI MOHAMED \\ Botany Dept., University of Malaya, 59100 Kuala Lumpur, Malaysia
}

\begin{abstract}
An exploratory floristic survey of the genus Mimosa was conducted in 1993 to ascertain species diversity and their spatial patterns of distribution in Peninsular Malaysia. A new species record of uncertain indigene, M.. quadrivalvis was recorded for the first time in restricted localities along the roadsides in Pekan Darat and Bertam, Seberang Perai, Gurun and Bedong in Kedah in addition to widely distributed and seemingly ubiquitous presence of M. invisa Mart. ex. Colla and M. pudica L. The latter two species were mostly found in open, disturbed and derelict habitats, agricultural areas and ex-mining lands. Both species exhibited largely contagious and overdispersed distribution patterns with positive peaks in pattern intensity values although regularity or underdispersed distribution patterns do manifest in certain localities. The giant mimosa, M. pigra inhabited in clustered thickets, large pockets of lands in the urban and sub-urban localities in the states of Penang, Perak, Kelantan, Kuala Lumpur and Negeri Sembilan. In other states, M. pigra was confined to a few localities in smaller patches. Except for M. quadrivalvis, the other species of Mimosa are serious weeds in the agricultural, recreational and residential and derelict areas. A key to the Mimosa species is constructed along with brief descriptions on their morphology and ecology.
\end{abstract}

Key words: Malaysia/Weed ecology/Mimosa invisa/Mimosa pigra/Mimosa pudica/Mimosa quadrivalvis/Weed distribution/Weed anatomy and morphology.

\section{INTRODUCTION}

The genus Mimosa, in the family Mimosaceae (syn. Leguminosae or Fabaceae) is large and cosmopolitan with 300-500 species worldwide (Holm et al. 1977; Nielsen 1981, 1983, 1992). The intricacy of this genus has made it a subject of continued research interest and taxonomic revisions (e.g. Ridley 1925; Corner 1952; Henderson 1959; Burkill 1966; Metcalfe \& Chalk 1972; Nielsen 1992). According to Index Kewensis (1991), there are well over 1800 binomials of Mimosa worldwide with heavy concentrations in tropical America. In Malesia, there are three introduced and naturalised species. Recent studies by Nielsen (1992) gave extensive accounts of the genus

*)

Paper presented at the Symposium on Biology and Management of Weeds and Fourth Tropical Weed Science Conference, 22 - 24 November 1994, Bogor, Indonesia 38 
on the world scale. In Malaysia, the genus Mimosa is known for its weedy elements viz. $M$. invisa, M. pigra and M. pudica infesting large areas of agricultural, residential, recreational, roadsides and derelict areas and ex-mining lands. Ridley (1925) gave the first account of the family in the Malay Peninsula while Burkill (1966) described a brief history of the various species that has been introduced into the Malay Peninsula. Waterhouse (1993) enlisted the three weedy species of Mimosa with the 15 to 19 ratings among the 140 most important weed species as appropriate targets for biological control in Southeast Asia in general and in Malaysia in particular.

This paper reports briefly on the morphology and distribution patterns of Mimosa spp. with emphasis on M. quadrivalvis L. var. leptocarpa (DC.) Barneby.

\section{MATERIALS AND METHODS}

An exploratory floristic survey was conducted in 1993 in Peninsular Malaysia to ascertain species diversity and spatial distribution patterns of the genus Mimosa. For such purpose, samplings were made at random in selected vegetable gardens, derelict areas, immature rubber and oil palm estates, ex-mining lands and roadsides. In addition, the list count quadrat (1m x 1m) method of Kim \& Woody (1983) was also used. In the case of M. pigra, the line transect method was used with quadrat size of $2 \mathrm{~m} \times 2 \mathrm{~m}$. Only adjacent and accessible areas close to the roads were sampled. A total of 72 quadrat samples for each species were obtained (Table 1). The spatial distribution date for each species were subjected to pattern analysis (Allinson 1981) with pattern intensity values used as indices to measure the departure from randomness. Detailed morphological comparisons were made between species.

Table 1. Plot size,number of transects and quadrats transects employed in pattern analysis of plant population of Mimosa species

\begin{tabular}{lccc}
\hline \hline Species & Plot size $(\mathrm{m})$ & No. of transects & No. quadrat/transect \\
\hline M. invisa & $1 \times 1$ & 12 & 6 \\
M. quadrivalvis & $1 \times 1$ & 12 & 6 \\
M. pigra & $2 \times 2$ & 12 & 6 \\
M. pudica & $1 \times 1$ & 12 & 6 \\
\hline
\end{tabular}




\section{RESULTS AND DISCUSSION}

\section{Pattern of distribution}

Figure 1 illustrates the extent of infestation of the four species of Mimosa in Peninsular Malaysia. Generally, heavy concentrations of M. pigra are found in ex-mining lands, ex-padi farms and derelict areas both in rural and urban localities in the states of Penang, Perak, Kelantan, Kuala Lumpur and Negeri Sembilan, often in clustered thickets and large pockets. Mimosa invisa and $M$. pudica are widely distributed and seemingly ubiquitous mostly in open, disturbed and derelict habitats, agricultural areas and ex-mining lands. The soils range from rather wet of the inseptisol, vertisol and entisol types or the relatively dry soils of the oxisol or ultisol types. Soil samples taken in areas where rampant infestations of Mimosa spp. occur registered $\mathrm{pH}$ values ranging from 4.0 - 5.0. Mimosa invisa and M. pudica are also found on the bris soil habitat in Terengganu, Pahang, Kelantan and Pantai Remis areas of Perak.

Clump sizes of adult populations vary considerably according to the species of Mimosa. In the case of $M$. pigra, it ranges from $1.0 \mathrm{~m}$ to $6 \mathrm{~m}$ in diameter while for $M$. pudica and $M$. invisa these were about $0.25 \mathrm{~m}-2.0 \mathrm{~m}$. Mimosa quadrivalvis has a relatively smaller clump size of about $0.2-1.0 \mathrm{~m}$ (Table 2). Genet populations range from $0.2-1.0 \mathrm{plant} / \mathrm{m}^{2}$ for $M$. pigra; $0.5-4.0$ plants $/ \mathrm{m}^{2}$ (M. invisa and $M$. pudica) to $1.0-5.02$ plants $/ \mathrm{m}^{2}$ for $M$. quadrivalvis, thereby emphasizing different morphology and growth habits of the different species of Mimosa (Table 2).

Table 2. Clump size and genet population density of Mimosa spp. in Peninsular Malaysia

\begin{tabular}{lcc}
\hline \hline Species & Clump size $(\mathrm{m})$ & Genet population density $\left(\right.$ per $\left.^{2}\right)$ \\
\hline M. invisa & $0.25-2.0$ & $0.5-4.0$ \\
M. quadrivalvis & $0.20-1.0$ & $1.0-5.0$ \\
M. pigra & $1.0-6.0$ & $0.2-1.0$ \\
M. pudica & $0.25-2.0$ & $0.5-4.0$ \\
\hline
\end{tabular}

The spatial distribution of the four species of Mimosa differed accordingly, showing pattern at different block sizes in different regions of survey. In the case of M. pigra population in the northern states of Penang, Perak and Kedah (Region a), pattern was observed with peak pattern intensity values at block size 12 . Similar clusterings were observed among $M$. pigra populations in Malacca, Negeri Sembilan, Johore (Region c) and Kelantan (Region d). Mimosa pigra populations in the Federal Territory, 

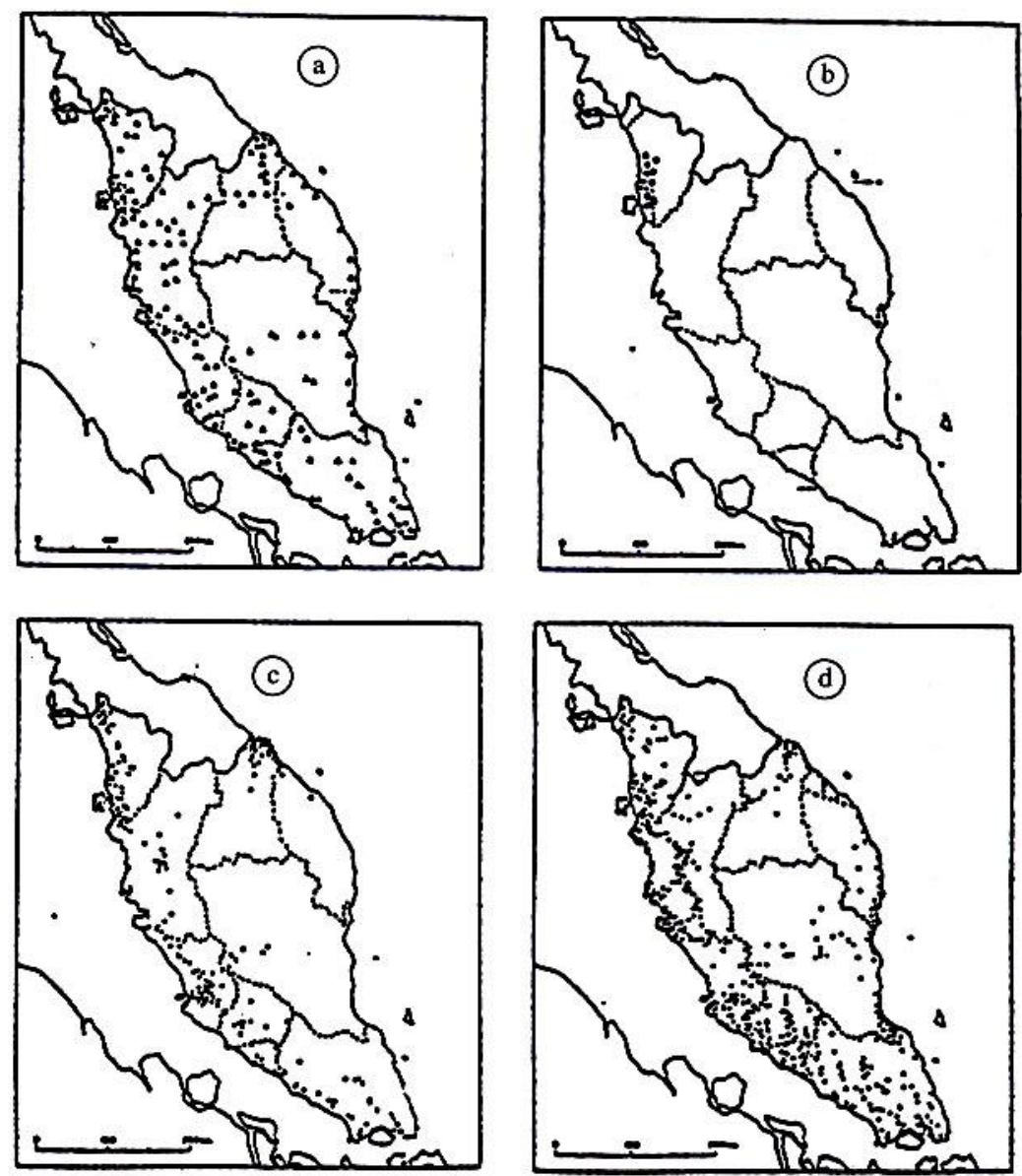

Figure 1. The distribution of (a) Mimosa invisa, (b) M. quadrivalvis, (c) M. pigra, and (d) M. pudica in Peninsular Malaysia. Each symbol represents at least one record within 5 m radius. 
Selangor (Region b) and southern Perak showed pattern at block sizes 8 and 16. A tendency towards regular undispersed spatial distribution was observed among $M$. pigra populations in Region b at block size 1 (Figure 2a).

Individual genets among $M$. invisa population for all regions showed regularity for block sizes 1, 2 and 3. Contagious overdispersed individuals were observed at block size 6 for Region $\mathrm{c}$ and block size 8 for Regions a, b and d (Figure 2b).

Regularity in spatial distribution of individuals of $M$. pudica was recorded at block sizes 1 , 2 and 3 for all Regions saved Region b. Positive peaks of pattern intensity values were recorded at block size 6 for Regions a, b and d and block sizes 6 and 16 for Region c (Figure 2c).

The spatial distribution of individual genets of $M$. quadrivalvis showed pattern at block size 6 but exhibited regularity at block sizes 1, 2 and 3 (Figure 2d).

No concrete arguments can be forwarded to explain the spatial heterogeneities exhibited by different populations of Mimosa pigra, M. invisa, M. pudica and $M$. quadrivalvis. Differential growth rates and differences in morphology among the species studied are too simple a notion to help illustrate such differences. Further analyses on the possible roles of environmental variables such as soil, $\mathrm{pH}$, nutrient status, soil types, etc. in explaining the spatial heterogeneities and distribution patterns of the different Mimosa species are needed.

\section{Morphology and Species Description}

Morphological illustrations and habit of M. quadrivalvis are shown in Figures 3 -6. Comparative morphological traits and characteristics of the species are shown in Tables 3 and 4.

1. Mimosa invisa auct. non Mart, ex Colla: Backer \& Bakh. f., Fl. Java 1 (1963) 561; Burkill, Diet. Econ. Prod. Mal. Penins. 2 (1966) 1498; Nielsen, Fl. Camb., Laos, Vietnam 19 (1983) 34, pi. 5: 1-7; Nielsen, Fl. Malesiana ser. 1, 2, 1 (1992) 184-185.

A procumbent perennial shrub, growing up to $3 \mathrm{~m}$ high. Stem conspicuously 4-angled, up to $4 \mathrm{~m}$ long, densely distributed with prickles. Leaves bipinnate, primary leaflets 4 to 9 pairs, leaflets opposite sessile 12 to 30 pairs, lanceolate, 6 to $12 \mathrm{~mm}$ long, $1.5 \mathrm{~mm}$ wide. Inflorescence a globular head, axillary, flowers pinkish violet, corolla 4-lobed with 8 pinkish violet exserted stamens. Fruit softly spiny, 3- to 4-seeded borne as clustered axillary, flattened pods, 1.0 to $3.5 \mathrm{~cm}$ long, 6 to $10 \mathrm{~mm}$ wide, splitting along the valves into 1 -seeded segments when mature. Seeds flattened, ovate light brown, rather glossy, 2 to $3 \mathrm{~mm}$ long. 

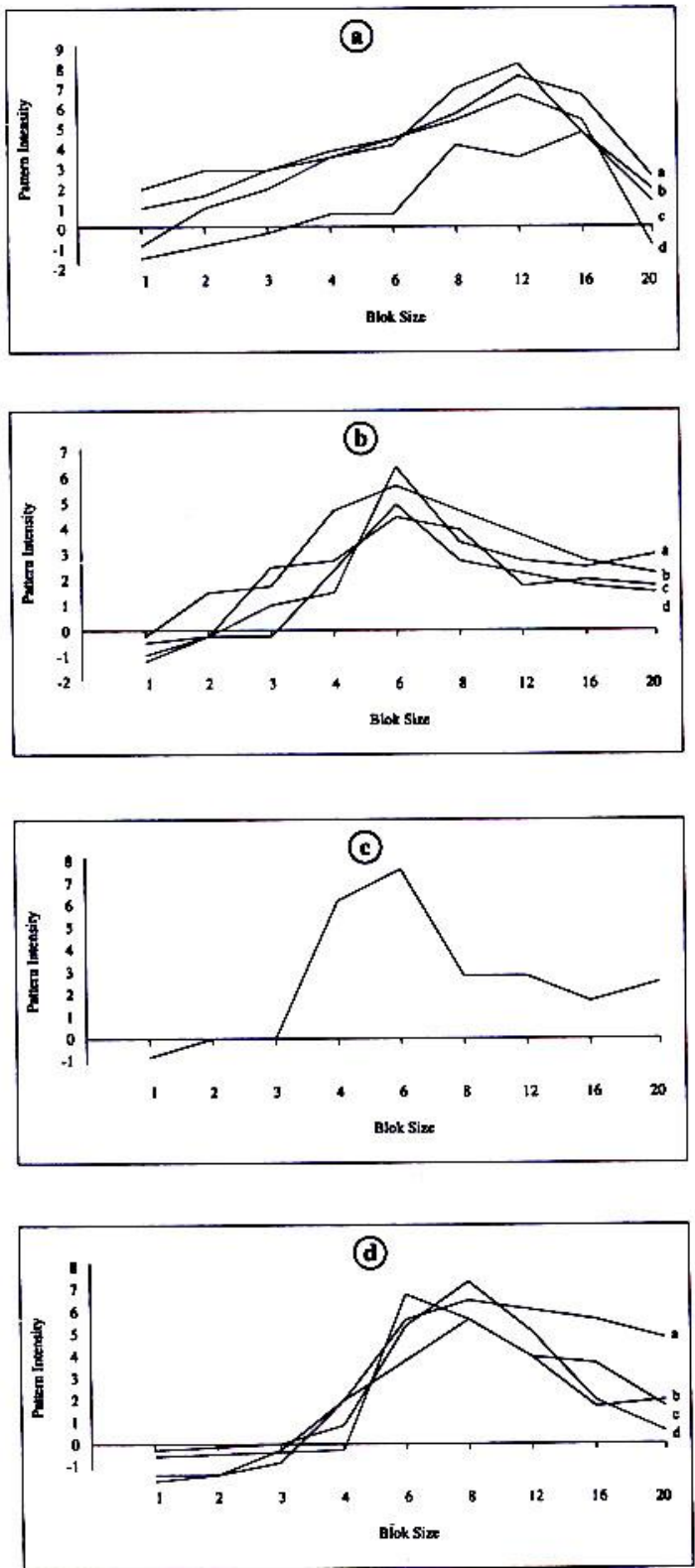

Figure 2. Pattern intensity values of spatial distribution of (a) M. pigra, (b) M. invisa, (c) M. quadrivalvis, and (d) M. pudica plants at different block sizes. Lower case letters on the curve denote regions of occurrence (see text for details). 


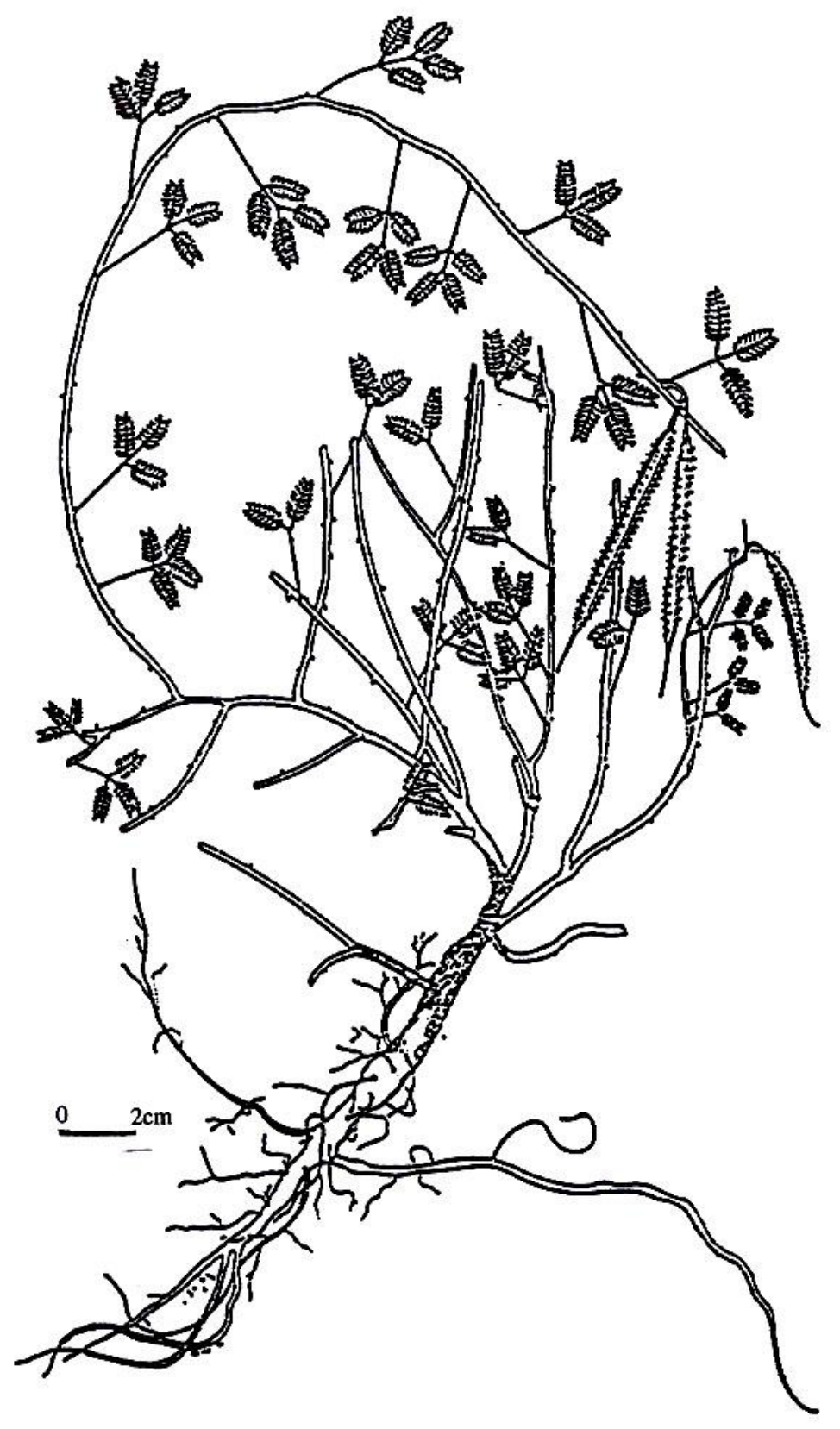

Figure 3. Mimosa quadrivalvis. 
The genus Mimosa - Baki, B. Bakar et al.

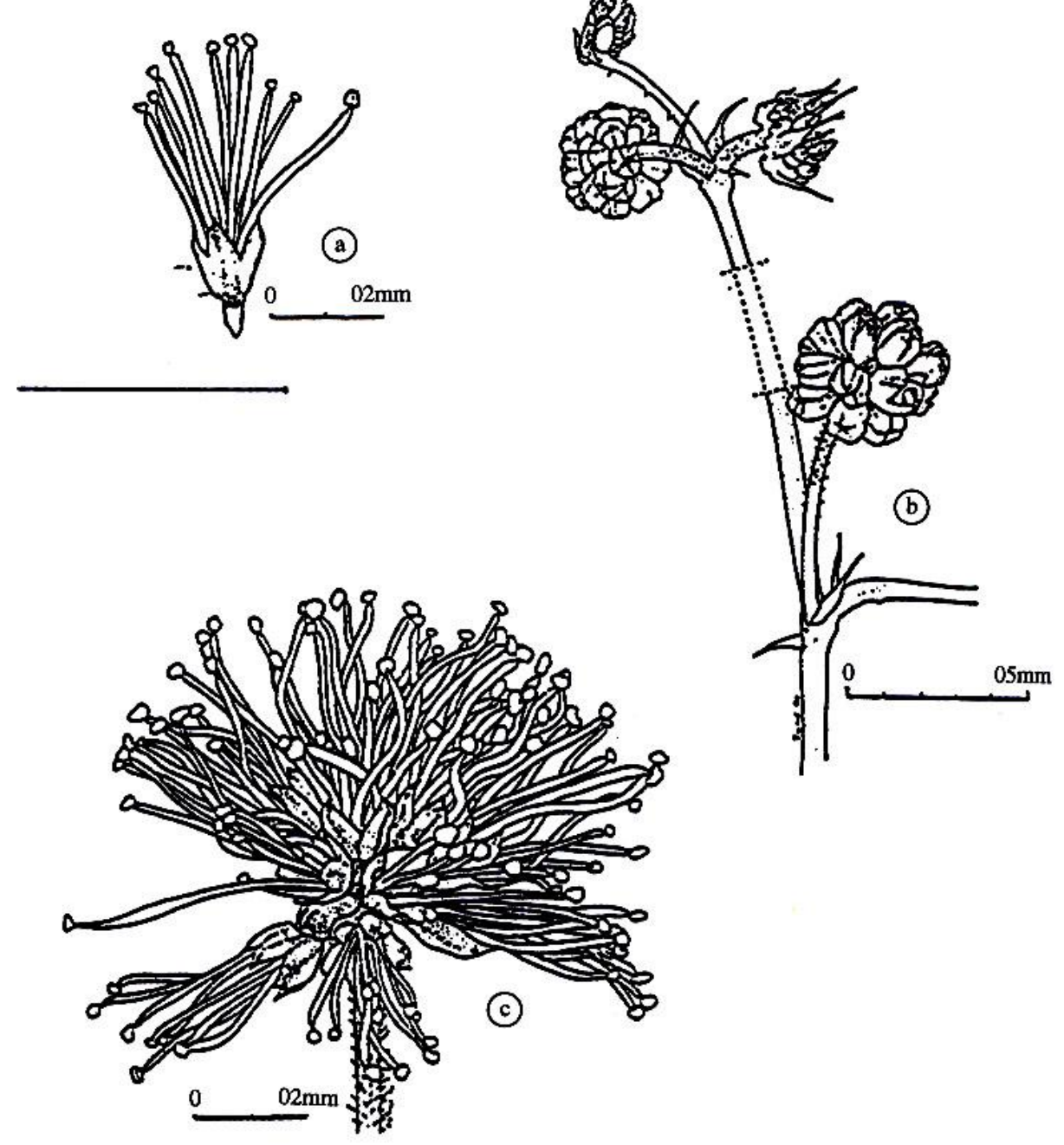

Figure 4. Mimosa quadrivdvis. (a) stamens, (b) axillary inflorescence, (c) opened flowers. 

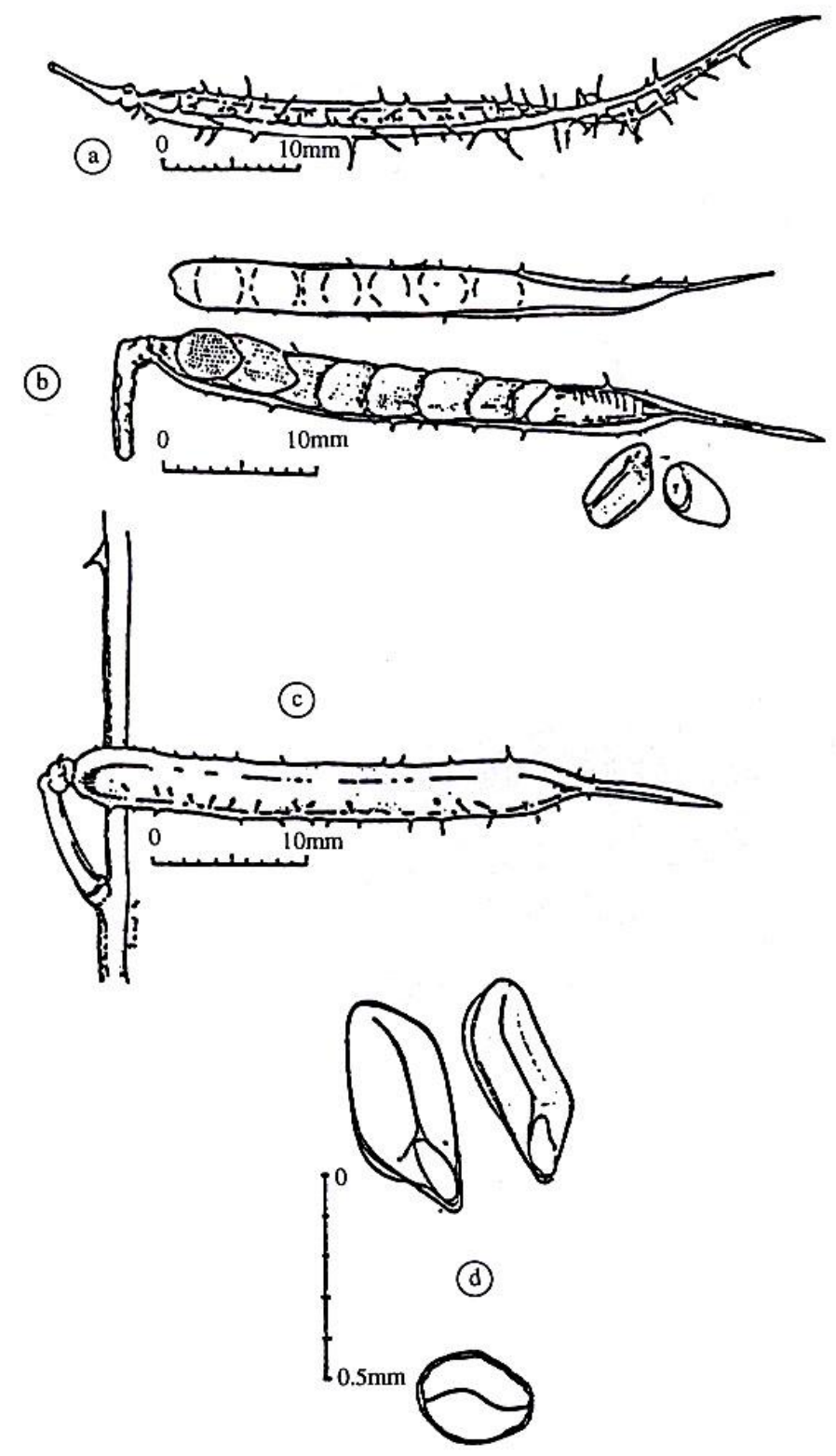

Figure 5. Mimosa quadrivalvis. (a) mature pod densely covered with long, fine prickles, (b) opened pod, (c) young pod, (d) seeds. 


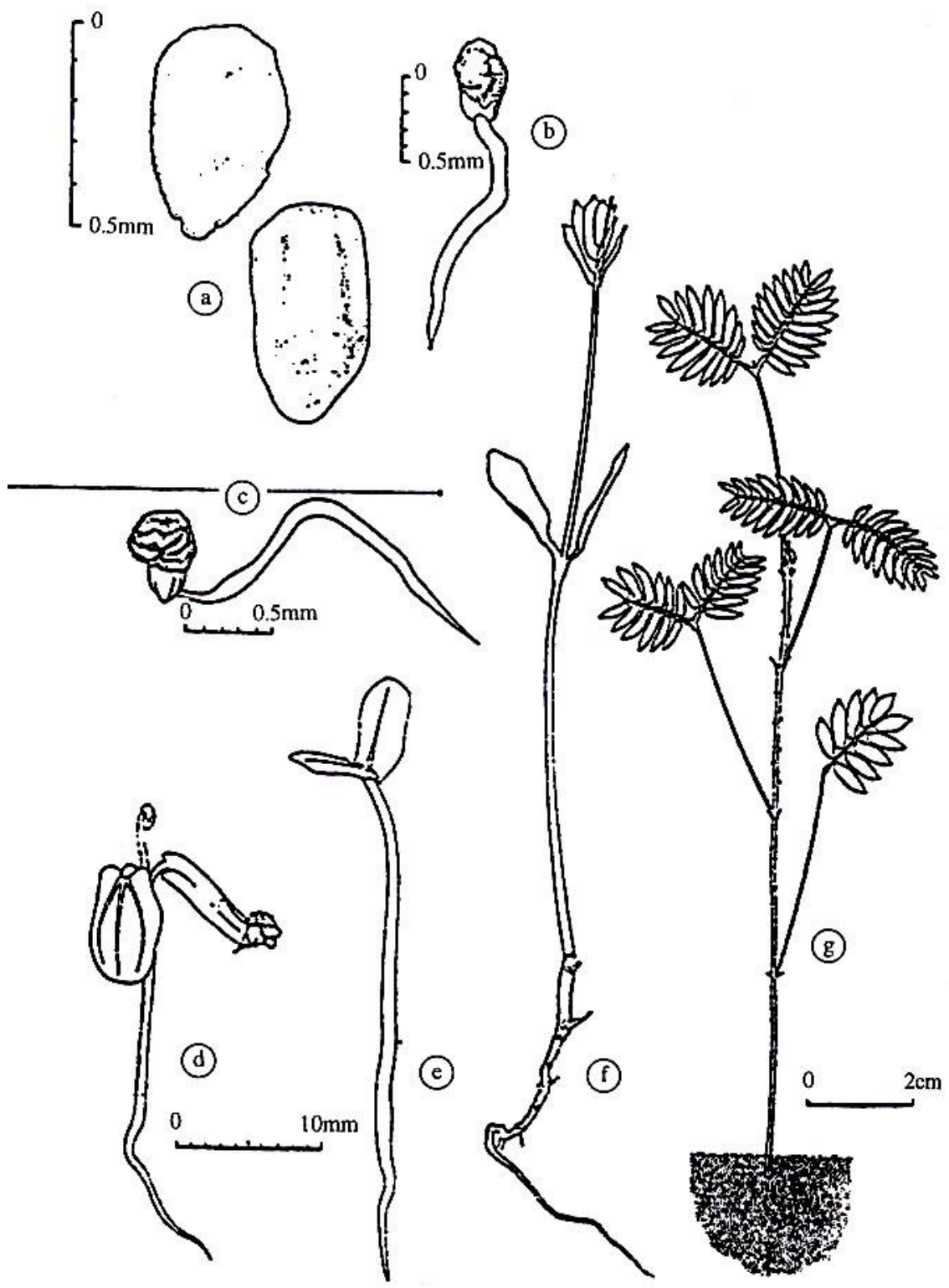

Figure 6. Mimosa quadrivalvis. (a) seeds, (b \& c) emergence of hypocotyl, (d \& e) hypocotyl with cotyledons, (f) emergence of once-pinnate, first true-leaf, $(\mathrm{g})$ young plant. 
BIOTROPIA No. 9, 1996

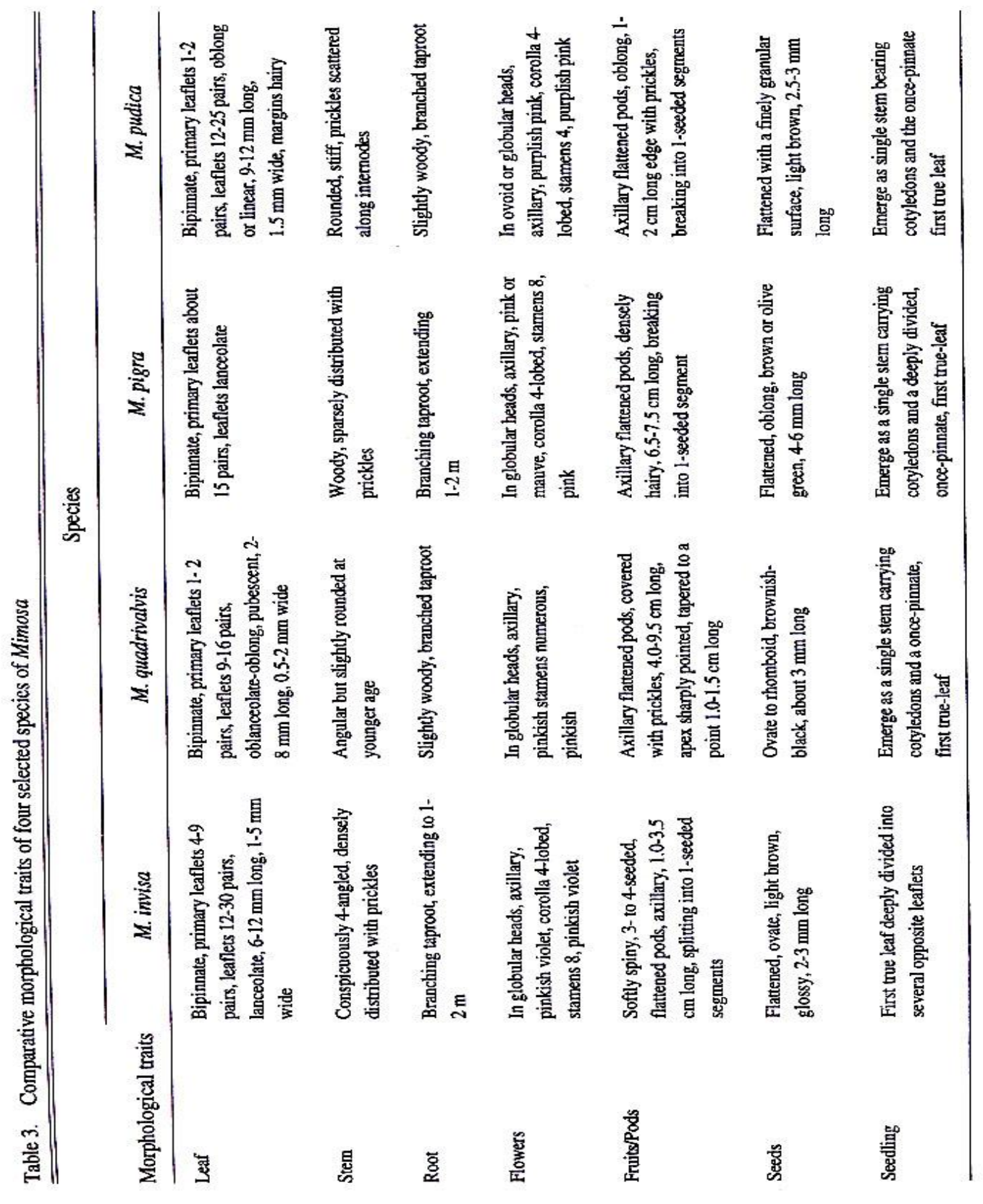


The genus Mimosa — Baki, B. Bakar et al.

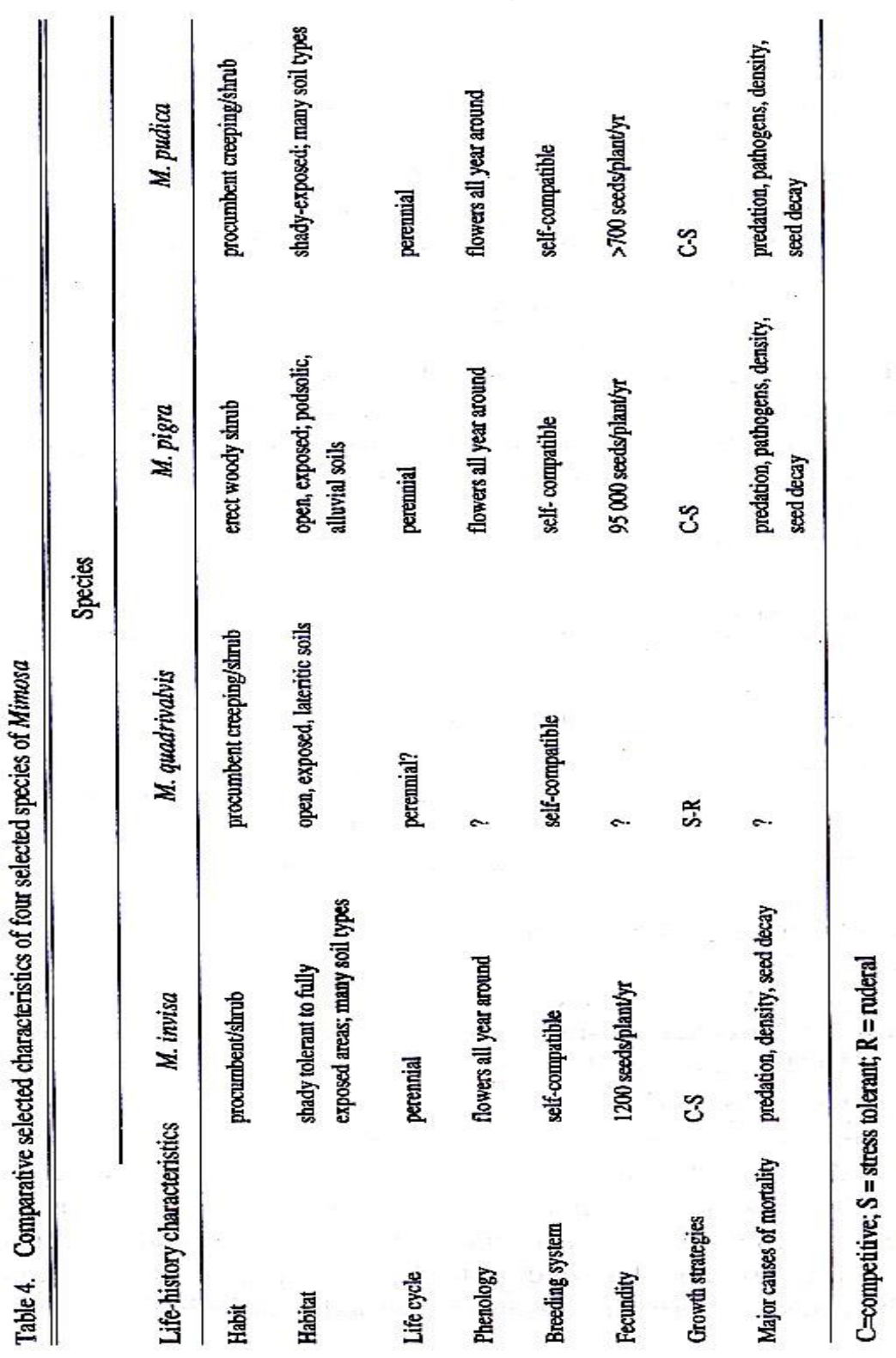




\section{Mimosa quadrivalvis L. var. leptocarpa(DC.) Barneby.}

A straggling shrub. Mature stem angular, prickles sparsely distributed; younger stem slightly rounded. Leaves evenly bipinnate, primary leaflets $1-2$ pairs, $0.5-1 \mathrm{~cm}$ apart from each other, leaflets opposite, 9-16 pairs, almost sessile, 2 - $8 \mathrm{~mm}$ long, 0.5 -2.0 mm wide, margin entire, pubescent, oblanceolate-oblong, both abaxial and adaxial surfaces sparsely distributed with glands and sparsely hairy but abaxial surface of outermost leaflet usually more hairy compared to abaxial surface of the inner leaflets. Secondary veins obscure, apex mucronate-truncate, base truncate. Secondary rachilla covered with short fine hairs, sparsely distributed. Inflorescence a globular head, axillary, 18 - 20 flowers per inflorescence. Stamen numerous, pinkish, 1.0 - $1.5 \mathrm{~mm}$ long, arranged in several rows forming a globular head. Bracts present, hairy. Fruits in axillary flattened pods, 1 - 3 in a group, usually the third one abortive, $4.0-9.5 \mathrm{~cm}$ long with prominent raised ridge along the edges, apex sharply pointed, tapered to a point $1.0-1.5 \mathrm{~cm}$ long, almost linear, moderately to densely covered with long, fine prickles, pedicel $0.8-1.1 \mathrm{~cm}$ long, hairy; mature fruits dehisce along sutures. Seed ovate to rhomboid in shape when dry, brownish-black, about $3 \mathrm{~mm}$ long.

3. Mimosa pigra L., Backer \& Bakh. f., Fl. Java 1 (1963) 561; Nielsen, Fl. Camb. Laos, Vietnam 19 (1981) 34, pi. 5: 8-14; Nielsen, Fl. Malesiana ser. 1, 2,1 (1992) 185.

Mimosa sepiaria auct. non Benth.: Ridley, Fl. Mal. Pen. 1 (1922) 656, p.p.; Burkill, Diet.

Econ. Prod. Mal. Pen. 2 (1966) 1499.

An erect, perennial woody shrub, growing up to $5 \mathrm{~m}$ high. Stem woody, up to $3 \mathrm{~m}$ long, sparsely distributed with prickles. Leaves bipinnate, primary leaflets about 15 pairs, leaflets sessile, lanceolate. Inflorescence a globular head, axillary, flowers pink or mauve, corolla 4-lobed with 8 pink stamens. Fruits densely hairy, 20- to 25-seeded axillary, borne as clustered flattened pods, 6.5 to $7.5 \mathrm{~cm}$ long, 7 to $10 \mathrm{~mm}$ wide, breaking into 1-seeded segments when mature. Seed brown or olive green, oblong, flattened, 4 to $6 \mathrm{~mm}$ long, $2 \mathrm{~m}$ wide.

\section{Mimosa pudica L., Backer \& Bakh. f., Fl. Java 1 (1963) 561; Nielsen, Fl. Camb. Laos}

Vietnam 19 (1981) 35, pi.; Nielsen, Fl. Malesiana ser. 1, 2 , 1 (1992) 185-186.

A procumbent, perennial, creeping shrub growing up to $50 \mathrm{~cm}$ high. Stem rounded, stiff, up to $150 \mathrm{~cm}$ long, prickles scattered along the internodes. Leaves bipinnate, primary leaflets 1 to 2 pairs, leaflets opposite, 12 to 25 pairs, oblong or linear, 9 to $12 \mathrm{~mm}$ long, $1.5 \mathrm{~mm}$ wide, margins hairy. Inflorescence an ovoid or a globular head, borne on prickly axillary stalks, flowers purplish pink, corolla 4-lobed, stamens 4, purplish pink. Fruits oblong, flattened 1- to 5 -seeded pod, 1 to $2 \mathrm{~cm}$ long, 3 to $6 \mathrm{~mm}$ wide, edge with prickles, borne in cluster on leaf axils, breaking into 1-seeded segments 
when mature. Seeds light brown, flattened with a finely granular surface, 2.5 to $3 \mathrm{~mm}$ long.

\section{Key to Mimosa species in Peninsular Malaysia}

1. Primary leaflets $1-2$ pairs

2. Leaflets almost sessile, pubescent, 2 - $8 \mathrm{~mm}$ long, 0.5 - $2.0 \mathrm{~mm}$ wide. Stem angular. Flowers pink, in globular heads, stamens pink. Pods 4.0 - $9.5 \mathrm{~cm}$ long, apex sharply pointed tapered to a point $1.0-1.5 \mathrm{~cm}$ long, covered with long, fine prickles ............................................................................................. M. quadrivalvis

2. Leaflets sessile, 9-12 mm long, $0.5 \mathrm{~mm}$ wide, margin hairy. Stem rounded. Flowers purplish pink, in ovoid or globular head, stamens purplish pink. Pods 1 - 2 $\mathrm{cm}$ long, edge with prickles M. pudica

1. Primary leaflets more than 2 pairs

3. Primary leaflets 4 - 9 pairs, leaflets lanceolate. Stem conspicuously 4-angled with numerous prickles. Flowers pinkish violet. Pods 1.0 - $3.5 \mathrm{~cm}$ long, 3 to 4 -seeded. Seed light brown, glossy, ovate, 2 - $3 \mathrm{~mm}$ long ..... M. invisa

3. Primary leaflets about 15 pairs, leaflets lanceolate. Stem woody, prickles sparsely distributed. Flowers pink or mauve. Pods $6.5-7.5 \mathrm{~cm}$ long, 20- to 25-seeded. Seeds brown or olive green, oblong, 4 - 6 mm long M. pigra

\section{ACKNOWLEDGEMENTS}

The authors are extremely thankful to Dr. G.P. Lewis of Kew Botanical Gardens, U.K. for identifying the species and Mr. Anuar Pandak and Mr. Zainal Mustafa for their technical assistance. Thanks are also due to Mr. Tan Lip Hong for typing the manuscript.

\section{REFERENCES}

ALLINSON, J.M. 1981. Numerical and experimental analysis of species relationships in grassland. PhD thesis, University of Wales.

BACKER, C.A. and R.C. BAKHUEEN VANDENBRINK. 1963. Flora of Java. Vol, 1. Rijksherbarium. Leyden. 547-565. 


\section{BIOTROPIA No. 9, 1996}

BURKILL, I. H. 1966. A Dictionary of the Economic Products of the Malay Peninsula. 2nd ed. The Crown Agent for the Colonies, London.

CORNER, E.J.H. 1952. Wayside Trees of Malaya. 2nd ed. Govt. Print. Off. Singapore, p 413.

HENDERSON, M.R. 1959. Malayan Wild Flowers. Dicotyledons. Malayan Nature Society, p 100.

HOLM, L.G., D.L., PLUCKNETT, J.V. PANCHO and J.P. HERBERGER. 1977. The World's Worst Weeds. Distribution and Biology. Univ. Press of Hawaii, Honolulu.

INDEX KEWENSIS 1991. Oxford University Press.

KIM, S.C and K. WOODY. 1983. Comparison of some methodologies for vegetation analysis in transplanted rice. Korean Journal of Crop Science 28(3): 310-318.

METCALFE, C.R. and L. CHALK. 1972. Anatomy of the Dicotyledons. Vol. 1. Oxford, Clarendon Press, p 487.

NIELSEN, I. 1981-83. Flora of Cambodia, Laos and Vietnam, Vol. 19.

NIELSEN, I.C. 1992. Mimosaceae (Leguminosae - Mimosoideae). Flora Malesiana ser. 1, vol. 2, prt. 1.

RIDLEY, H.N. 1922. Flora of Malay Peninsula Vol. 1. Reeve and Co. London .

WATERHOUSE, D.F. 1993. The Major Arthropod Pests and Weeds of Agriculture in Southeast Asia: Distribution, Importance and Origin. ACIAR, Canberra. $141 \mathrm{p}$. 